\title{
The Sounds of Babel: Staging American Ethnic Diversity in Early Nineteenth-Century New Orleans
}

\author{
Nathalie DESSENS \\ Université de Toulouse-Jean Jaurès, France \\ Département d’Études du Monde Anglophone \\ dessens@univ-tlse2.fr
}

\begin{abstract}
In the early nineteenth century, Noah Webster proclaimed the existence of an American voice, distinct from the British one from which it originated. But was there really a single American voice? Could there be American voices? This paper examines the possibility of a multiplicity of voices. The main stage is New Orleans, although not the musical stage as might be expected. In early American New Orleans, indeed, travelers and sojourners described the city through its sounds, always qualified as both unusual and specific. To narrate their encounter with the city, most foreigners used the same metaphors-Babel, frogs in a marsh, noises specifically connected to one nation or another. This paper examines the way in which newcomers to early American New Orleans staged the city's ethnic diversity in their narratives by referring to sounds and voices, suggesting that, instead of the single American voice Webster had hypothesized, the early nineteenth century was one of voices which could, however, be called American.
\end{abstract}

Keywords: Early American New Orleans; Ethnic Diversity; Languages; Voices; Travel Narratives

In 1828, with the first edition of his famous American Dictionary of the English Language, Noah Webster set forth the principle that there was an American tongue, distinct from the British one that had been at its origins. In a 1789 essay, he had already advocated the establishment of schools and some uniformity in the use of books so as to "annihilate differences in speaking and preserve the purity of the American tongue” (1789: 19). But was there really a single American tongue? Could there be American tongues? The present essay will examine the possibility of multilingualism in nineteenth-century America, taking as the main stage the city of New Orleans. When people think about New Orleans, they instantaneously think of the cradle of jazz music, and when they think of staging sounds in New Orleans, they immediately picture the musical stage. There are, however, other sounds of New Orleans that can be subtler, less obvious, and nonetheless revealing.

As this essay will argue, in early American New Orleans, travelers and sojourners described the city through its sounds, which are always qualified as both unusual and specific. To narrate their encounter with the city, many foreigners used the same metaphors to describe what they heard-frogs in a marsh, noises identified with 
nations other than the United States, and, more importantly, Babel. This essay will examine the way in which newcomers to early American New Orleans staged the city's ethnic diversity by referring to sounds and voices in their narratives, and what this reveals about New Orleans and about the early American republic.

\section{THE BABEL OF THE SOUTH}

New Orleans was, in the early nineteenth century, an extremely cosmopolitan city. Many different population groups filled its streets and public places. There were, of course, the old Francophone inhabitants, the Creoles. There were a few Spaniards who had come during the Spanish colonial era, although Louisiana was never, for Spain, a settlement colony. Beside the colonial officers, very few people emigrated from Spain (save a few hundred Canary islanders who mostly settled outside the city) and the few who stayed in town ended up blending into the Creole population. For instance, all the governors of the Spanish period married Louisiana Creoles. A third important group, the Anglo-Americans, also started reaching Louisiana, from the Southeast, in particular, in the last decade of the eighteenth century. ${ }^{1}$

In the last years of the colonial period and in the early years of the American era, a major migratory flux reached Louisiana, that of the refugees from the Haitian revolution. Between 1791 and 1810, more than 15,000 former inhabitants of the French colony of Saint-Domingue found refuge in New Orleans (Dessens 2007: 1). The major influx, with 10,000 people, distributed in roughly equal thirds between slaves, free people of color, and whites, came in about six months from Cuba in 18091810, instantaneously doubling the population of New Orleans (Dessens 2007: 2728).

Throughout the first half of the nineteenth century, in-migrations continued by the thousands. The most numerous groups were those of the French nationals and AngloAmericans, both reaching the Crescent City in uninterrupted flows. There were also Spanish people fleeing revolution and independence in Latin America, especially from Mexico but not exclusively. German and Irish people also came in significant numbers, although the bulk of the Irish immigration came only in the 1840s, in the wake of the potato famine. Finally, although in more anecdotal numbers, people came from Italy and from several other European countries. ${ }^{2}$

All in all, the little town of some 8,000 that went from French to American rule in 1803 grew to become the third largest city in the United States by 1840, behind New

\footnotetext{
${ }^{1}$ For more information on immigration to Louisiana, see Brasseaux 1996.

${ }^{2}$ For details on these in-migrations of the first six decades of the American period, see Bourdelais 2012.
} 
York and Philadelphia, and on par with Baltimore. ${ }^{3}$ The population growth was such that, in 1840, more than half the population of the city was foreign born (Upton 2008: 41). While French-speaking people represented $83 \%$ of the city's population in 1810, the ethnic groups peopling New Orleans became increasingly more varied, to the point that, in 1860, the Francophone group represented only $39 \%$ of the population, the Anglophone group amounting to $41 \%$, and the rest of the population being distributed among German speakers (17\%) and speakers of Spanish and Italian (2\%) (Bourdelais 2012: 376).

Being a port city, the second largest port in the United States after New York City, with connections to Europe, the Caribbean, and Latin America, New Orleans also received many travelers who came for transient stays or longer sojourns and it was not unusual to find people from Latin America or the Caribbean who came to do business in the city. When examining the figures of arrivals of alien passengers in the main port cities of the young republic from 1820 to 1860, New Orleans appears as one of the two leading destinations for foreigners reaching the United States. With 555,322 arrivals, it accounted for $10 \%$ of the total influx $(5,457,914)$, ranking only behind New York, which welcomed 3,742,532 foreigners. ${ }^{4}$

Although this cosmopolitanism was not unusual in the Atlantic cities of the young American republic, which all received many contingents of Saint-Domingue refugees, as well as Irish and German people, New Orleans, because of its geographical situation and its colonial past, continued to attract French-speaking and Spanishspeaking immigrants, either from Europe or from the American colonial empires of these two nations. The linguistic situation, with two prevailing groups, AngloAmericans/British/Irish and Creoles/Saint-Domingue refugees/French immigrants, also made the situation of the city extremely unusual in the country. From the 1840s onward, the linguistic duality of the city became increasingly more apparent, to the point that parity between the two linguistic groups was reached in the last years of the antebellum period. ${ }^{5}$ This situation was nowhere to be seen in the rest of the young republic. It is thus interesting to examine the way the strangers to the city described this linguistic wealth, to assess their perception of New Orleans' languages and of the city in a larger perspective.

${ }^{3}$ These are the population figures for the $1803-1840$ period: 1803 : 8,$000 ; 1810: 17,242$ (7th US city); 1820: 27,176 (5th, +57.6\%); 1830: 46,082 (5th, +69.6\%); 1840: 102,193 (3rd, +121.8\%), US Bureau of the Censuses, Population of the 100 largest Cities and Other Urban Places in the United States: 1790 to 1990, http://www.census.gov/population, accessed April 2008.

${ }^{4}$ Boston was behind (with 388,195), as was Philadelphia (with 239,057), and Baltimore (with 231,314) (Albion and Pope 1939: 418).

${ }^{5}$ In 1840, there were 6,344 French-speaking heads of households for 3,788 English-speaking ones. In 1850 , the figures were 7,925 and 6,092, respectively. In 1860, the situation was, for the first time, reversed, with 12,813 Francophones and 13,540 Anglophones (Bourdelais 2012: 377). 


\section{THE SOUNDS OF BABEL}

Upon arriving by boat to the city on a foggy morning, the attorney and architect John Latrobe wrote:

A sound more strange than any that is heard anywhere else in the world astonishes a stranger. It is a most incessant, loud, rapid and various gabble of tongues of all tones that were ever heard at Babel. It is more to be compared with the sounds that issue from an extensive marsh, the residence of a million or two of frogs, from bullfrogs up to whistlers, than anything else. It proceeds from the market and levee, a point to which we had cast anchor. (1986: 160-61)

Latrobe actually heard the city before he saw it being laid open to his view "in a moment, by the sudden disappearance of the fog." The rest of his description dwells on "the strange and loud noise," the "noisy folk," and the people that "appeared to strain their voices to exceed each other in loudness" (1986: 163). Describing his arrival at the place where he was staying, at the Tremoulets', he insists again on "the noise and gabble [that was] so incessant that Tremoulet, seeing [him] look with astonishment at the vociferous party, thought some sort of an apology necessary and said 'Voyez vous, nous autres Français sont un peu bruyans'” (1986: 166). He goes on to describe a meeting of Blacks playing music and dancing in the street, again repeating that this made "an extraordinary noise" and, a few lines down, "an incredible noise” (1986: 180). On the next page, he speaks of "a considerable noise," and again an "abominable, loud noise," detailing the sound of the drums, the "uncouth song," and the women who "screamed a detestable burden on one single note" (1986: 181).

Whatever the period of their travel or sojourn, the strangers to antebellum New Orleans filled their descriptions with references to those aural experiences. Noises unheard anywhere else were what often first struck the travelers. Noises sometimes sounded unpleasant, but were also often enjoyable to the newcomers. Pierre Clément de Laussat, the short-lived administrator of French Louisiana, in December 1803, marveled at the various types of music played at a ball, "boleros, gavottes, English dances, French and English quadrilles and gallopades" (1978: 86). In most descriptions, the streets are said to be "noisy with traffic" (Martineau 1838: 259) and "the very air howl[ed] with an eternal din and noise," as Alabama visitor Albert J. Pickett noted (qtd. in Upton 2008: 46). A few decades earlier than his son John, the famous architect Benjamin Latrobe had found even the mosquitoes noisy: "Their noise is so loud as to startle a stranger at its daily occurrence," and, like his son some two decades later, he is reminded of a concert of frogs in a marsh (2007: 256).

Whatever their nature, noises are always described as unusual, in particular because of the foreign tongues heard in the city, some of them native to the city. British social theorist and abolitionist Harriet Martineau, for instance, notices that 
"the negroes who passed shouted their very peculiar kind of French" (1838: 250). Later, she describes the market, writing that "the groups of foreigners make a Babel of the place with their loud talk in many tongues" (1838: 262). This variegated character of the languages was also what struck Frederick Law Olmsted when he traveled to New Orleans. In his Journey In the Seaboard Slave States in the Years 1853-1854, he recounts being struck by the "French noises," although he does not say why they were French to him, adding that he "was confused with the loud French and quiet English of the crowd" (1856: 580).

John Latrobe and Harriet Martineau were not the only ones to compare New Orleans to the multilingual biblical city and Babel is indeed the most common reference in all the narratives about early American New Orleans. For instance, French traveler Fontaney marveled at "the mixture of voices [that] spoke every language," going on with the most original description of this plurilingual experience: "There was the by God of the Yankee, the per la Madona (sic) of the Italian, the Carambe (sic) of the Spaniard, the Diou bibant of the Gascon, the guttural God dam of the Irishman [...] In all a living Babel” (qtd. in Reinders 1998: 33). Reverend Joseph Holt Ingraham, in his famous The South West by a Yankee, thought he had met in New Orleans "the representatives from all the unlucky families which, at the building of Babel, were dispersed over the earth” (1835: 90). Similarly, English traveler Charles Murray echoed: "The prevailing language seems to be that of Babel Spanish, Portuguese, French, English, mixed with a few wretched remains of Choctaw, and other Indian tribes, and all these spoken in the loudest, broadest, and strangest dialects" (1839: 189). And the Swiss Berquin Duvallon simply stated "It is a tower of Babel” (1806: 48).

Besides music, languages seem to have represented the most notable sounds of the city to unaccustomed ears and indeed the travelers insisted on this linguistic plurality. "Every nation seems to be represented [...] from the hardy Scotch and Swede of the north to the tawny Maltese of a warmer clime, each jabbering away in his native tongue like so many monkeys," Henry Whipple, the future Episcopal bishop of Minnesota, writes in 1844 (1937: 95-96), in a style that reflects the strangeness of this linguistic experience to the Anglo-Saxon, as well as a clear feeling of superiority. Paul Wilhelm, the Duke of Württemberg, added "the ear of the stranger hears every conceivable language of the educated and uneducated world" (1973: 32-33). In Choctaw, New Orleans was even referred to as "Balbancha," which means "a place of foreign languages" (Usner 2003: 112).

Quite clearly all those who came to New Orleans noted this diversity and their descriptions are full of aural and visual depictions of ethnic varieties. There are two recurrent types of metaphors in the travelers' descriptions. Babel is the most frequent one, implying some form of criticism from the part of the authors. The Biblical narrative indeed suggests that, to punish men for their hubris and to prevent them from building a tower that reaches the sky and becoming too powerful to check, God "confound[ed] their language, that they may not understand one another's speech" 
(King James Bible, Gen. 11.7), until then common, and dispersed them over the face of the earth. The travelers in general, used to a single national language, were annoyed by the linguistic variety they encountered. The Anglo-Saxons in particular, who were at that time attempting to build a national cohesion in the very young American republic, most probably found this widely accepted variety problematic since they deemed that a common language was indispensable for the growth of their new nation.

As for the British visitors, they tended to cringe at the unusual character of these people so different from their usual standards. Those Catholics, who lived in what appeared as sin, holding slaves, living in the midst of the free people of color who were the living proof of racial mixing, were seen as sinful and their language, foreign to the ear, debased by Creole tones, as Martineau's testimony suggests, was the epitome of this unacceptable difference. This probably also accounts for the second mostly used type of metaphor, the animal one. From the Latrobes, who compared the New Orleans voices to the sound of frogs in a marsh, to Henry Whipple, comparing New Orleanians to monkeys, the Anglo-American visitors criticized not only the language, but most probably the relaxed interracial relationships so foreign to their own biracial vision of social order. This linguistic diversity, fraught with African accents, was some kind of divine punishment on the sinful society of New Orleans. That New Orleans kept being described as the Babel of the South or the Babel of the United States requires further analysis.

\section{THE SOUNDS OF DIVERSITY?}

The writers cited may be assumed to have seen nothing but the Northeastern United States or Europe and to be experiencing a cultural shock in their first encounter with a city of the American South. This is untrue. Most of them had traveled through other regions of the South on their way to New Orleans. Benjamin Latrobe always insisted on his wide range of experience as a traveler. He was coming from the state of Virginia, which the early chapters of his narrative describe. Both Martineau and Olmsted had come by way of Alabama and reached New Orleans by steamboat along the Gulf Coast and into Lake Pontchartrain, then taking the railroad to get to the city. Robin was not new to the South either, as his narrative shows. Yet, despite their acquaintance with the South, all of them insisted on the absolute originality of their New Orleans experience. The Crescent City was like nothing they had ever seen before. And this exceptionalism can be, in all of these cases, connected with the sensorial experience most travelers immediately had upon reaching the Crescent City.

Moreover, many American cities of the Atlantic space were also cosmopolitan and most of the travelers cited in this chapter had lived in or visited other Atlantic cities of the young American republic before coming to New Orleans. Most of the narratives of the foreigners, for instance, started in the port cities where their boats had reached 
the United States. The Anglo-American visitors knew cities like New York, Baltimore, or Philadelphia, which included many foreign-born inhabitants speaking strange languages. Architect Benjamin Latrobe, who had immigrated to the United States from Britain in 1795, for instance, had lived in the East. He had participated in the building of the Capitol in both Washington and Richmond, the Bank of Pennsylvania and the city water system in Philadelphia, as well as the cathedral of Baltimore. Henry Whipple, to take just another single instance, had been born and raised in New York. All of them were seasoned to cosmopolitan environments. Yet, only New Orleans triggered such an abundance of comments which were common to all the travelers. There was thus, in New Orleans, something different, something the strangers found striking and specific.

Diversity, it is true, might have been slightly greater than elsewhere. Like in many other cities, the presence of the English, French, German, and Italian languages was obvious. New Orleans, however, also welcomed Spanish-speakers, either from Spain, from Cuba, or from Mexico, especially after the Mexican independence, probably because Louisiana had been for almost four decades a Spanish colony, because it was at the intersection of the Anglo-American and Hispanic worlds, and because its important port activity maintained close links with the Hispanic world. There were, for instance, regular lines between New Orleans, Cuba, and Tampico. Moreover, the public space was largely open to free people of color and black slaves. Free people of color, who represented an important proportion of the city's population - up to almost one fourth in 1840 - were in greater numbers than in any other city of the American South. Their presence in the public space, as free persons, was increased by the slaves who also had a relative freedom of movement in this urban space, making up the quasi-totality of the people who sold or purchased on the many markets of the city, and even allowed a dedicated space to meet, play music, and dance on Sundays, the famous Congo Square. The presence of black people was not uncommon in the other Atlantic cities, but the public space was probably less open to them. Except for Philadelphia (Upton 2008: 117), no other city was known for having a space dedicated to the singing and dancing of blacks, free or enslaved, and Congo Square was at the heart of the auditory surprises (and shocks) of the strangers to the city. Other groups also shared the public space. Native Americans, for instance, were present in the streets and the markets, and are mentioned in most descriptions. Olmsted, for instance, noted that "in the crowded market-place, there were not only the pure old Indian Americans, and the Spanish, French, English, Celtic, and African, but nearly all possible mixed varieties of these, and no doubt of some other breeds of mankind" (1856: 581).

This significant ethnic and racial mixture, probably shocking to newcomers from Europe, might account for the use of the Babel metaphor which, biblically, implies a kind of punishment suggesting a required atonement. In most travel narratives, indeed, it is the ethnic, social, and racial mixing in a relatively open environment seemingly placing all groups on an equal footing - that apparently troubled the 
visitors. In his Three Years in North America, British traveler James Stuart recounts his amazement at witnessing "Negroes, Mulattoes, French, Spaniards, Germans, and Americans [...] all crying their several articles in their peculiar languages" (qtd. in Upton 2008: 85), while Benjamin Latrobe adds a social dimension to the mixing, describing "white men and women, and of all hues of brown, and of all classes of faces, from round Yankee to grizzly and lean Spaniards, black negroes and negresses, filthy Indians, half naked, mulattoes curly and straight-haired, quadroons of all shades, long haired and frizzled, women dressed in the most glaring yellow and scarlet gowns" (2007: 162-63). The richly dressed quadroons mingling with the halfnaked unkempt Indians and the white Europeans and Americans most certainly triggered negative reactions among the travelers unused to such sights. The relative nudity of some of these New Orleanians might also have called forth the animal imagery often used by the visitors, as well as the suggestion of sin connected with Babel. To the more puritan eyes of the British or Northern Anglo-American visitors, nudity and the obvious display of racial mixing could not but trigger a strong reprobation and sense of superiority which suggested the metaphors they recurrently used to comment on their unusual and unexpected experience.

The linguistic and cultural context of New Orleans was also extremely different from what the travelers knew or had witnessed elsewhere in America, even in the cosmopolitan Atlantic cities of the Northeast. While, in other cities, the progress toward linguistic uniformity was constant, in New Orleans, linguistic diversity seems to have mattered much less than elsewhere, due to the colonial past of the city. Firstly, its colonial past mattered, because it had taught New Orleanians a degree of tolerance to languages. Spanish and French had coexisted peacefully, including in most official documents. To give a single example, the records of the St. Louis Cathedral were kept in the native language of the recorder. The sacramental records, for instance, were kept in Spanish even when Louisiana briefly returned to France, between 1800 and1803, which is hardly surprising since this retrocession was long kept secret, but, more interestingly for the analysis, even after it was purchased by the United States. No attempt was made to keep the records in English or even to introduce bilingualism, even when the Irish or German presence in the Church made it less of a Latin stronghold. As long as the record keepers were of French or Spanish language, they could continue to record all the religious events of the lives of the New Orleanians in the language that was most natural to them. The colonial past also mattered because the transfer to Spain had shown the French-speaking population that belonging to another nation did not necessarily imply having to discard one's native language and cultural specificities. During the Spanish era (1763-1800), indeed, the Hispanic linguistic influence had been almost non-existent and had not appeared as a threat to the French speakers, whether in the official life of the colony or in the pursuit of everyday activities. The attitude of the Gallic population was thus extremely relaxed toward Spanish and they were originally unprejudiced against other languages. 
In the late eighteenth century, tolerance to linguistic difference was high in Louisiana, especially among the speakers of French because they were used to the sounds of a foreign language and because understanding between French people, Catalans, Spaniards, and Italians was most certainly possible without mastering the other's language. The purchase of Louisiana by the US, nevertheless, marked a turning point in the political and social conception of language. Because the AngloSaxons started flocking into Louisiana - as the new owners of the territory, at that the new competition and clash of cultural and linguistic traditions "made language a point of social rupture" (Upton 2008: 41) and a powerful symbol of identity. The practice of the various languages was what brought the communities together and differentiated them from the rest of the population, making it all the more necessary for their members to defend the use of their mother tongue. Language diversity was thus obviously a fact of the city, reinforced by the ongoing competition between the new Anglo-American rulers, to whom the Irish and British migrants often aggregated, at least linguistically, and the old Creole population to which the Saint-Domingue refugees and French migrants easily aggregated to counterbalance the mounting Anglophone power. Progressively, two linguistic groups began to prevail, the minority linguistic groups joining forces with one of the two dominant groups, the Italian migrants and Spanish-speaking newcomers manifestly aggregating to the Francophone population, at least linguistically. It is precisely this dual linguistic situation that differentiated New Orleans most from the other cosmopolitan cities of the Atlantic world, making it a unique and contested melting pot.

\section{A CURSE OR THE HAND OF PROVIDENCE?}

The reference to Babel implies both diversity and impossible communication. If this is probably what the foreigners felt when visiting the city, it is most certainly not the way in which New Orleanians would have described the plurilingual context of their city. If the competition between Anglophones and Francophones was a fact, there are many signs that the two linguistic communities communicated better than what is most often believed. Furthermore, the impression most often conveyed by the insiders was one of plurality and interaction rather than one of division and opposition.

First of all, there are clear signs that the French and English languages coexisted in the public spaces of New Orleans. The Civil Code of 1808, for instance, was bilingual, as was its 1822 revised version. This is not surprising as it followed the general precepts of the Louisiana Purchase Treaty which, although it did not stipulate anything on linguistic questions, indicated that the population of the territory of Louisiana was "maintained and protected in the free enjoyment of their liberty, property and the Religion which they profess.” To the Gallic group, it also guaranteed the persistence of their cultural differences. More surprisingly, however, in a new territory, then state, of the United States, in case of legal contention, the French 
version of the Code was authoritative, as the native language of its authors was French and as the English version was a mere translation of the original French text. Similarly, all of the dozens of newspapers of the early American decades were in French, since the press was one of the reserved domains of the Saint-Domingue refugees who founded them, edited them, and constituted the majority of its writers. Le Moniteur de la Louisiane, founded in 1794, the first Louisiana newspaper, as well as Le Télégraphe, started in 1803, Le Courrier de la Louisiane, which ran from 1807 to 1860 , or L'Abeille de la Nouvelle-Orléans; all the most widely read newspapers were manned by Saint-Domingue refugees and published in French (Dessens 2007: 86-87). After 1830, although some of them remained in French, including L'Union, the first black newspaper founded during the Civil War, most became bilingual, French and English almost systematically coexisting throughout the antebellum period. L'Ami des Lois, l'Abeille de la Nouvelle-Orléans, le Courrier de la NouvelleOrléans, and even La Tribune de la Nouvelle-Orléans, the first black daily newspaper in the United States, founded by Louis Charles Roudanez in 1864, had sections in the two languages. Both languages were thus in use, including in legal and official matters. A resident in the city mentions people who spoke "the three languages, French, Spanish, and English" (Boze to Sainte-Gême, Sainte-Gême Family Papers, F 220, emphasis added), the use of the definite article here being of importance and suggesting the normalcy of at least some degree of multilingualism, in agreement with the unusual colonial history of the city

Furthermore, sources reveal an ever-growing interest in learning French and English. The fact that foreigners were still learning French in 1830 is evidenced through the publication of the New Orleans teacher Charbonnier's grammar, a book that enabled pupils to study more easily and more quickly "and for foreigners to learn, with his simple method and his good principles, the French language correctly and promptly, so that he has had very important sales in this city" (Boze to Sainte-Gême, F 164). But the French-speaking population was also learning English at an increased speed. In 1819, already, a resident in the city mentions a young Creole of color attending English classes "for without this language, it is impossible today to find a favorable position either in commerce or in any other field" (F 143). In 1834, the same resident says that he wishes his own granddaughters could have been educated at the Poydras hospice, "all the more because the English language is strictly practiced there, which would have been very useful to them upon entering society" ( $F$ 260). He also mentions the difficulty of finding a position for a newcomer from Southwestern France, because positions are scarce, even for those who speak English, and since "to do commerce, you need to know the English language" (F 265). English is "the main basis for the progression of the newly arrived," since it is "greatly appreciated by the Americans and the merchants of various nations who have established themselves in this city," and has become "the absolute necessity, principally for merchants" (F 280). As evidenced by Charbonnier's publication and the many comments the resident makes on the necessity of learning English to 
manage economically and socially in New Orleans, French speakers studied English and foreigners still tried to master French. People read bilingual newspapers and probably increasingly read the two sections (at least in part) since the two sections contained articles on very different subjects, ${ }^{6}$ as evidenced by the comments made by our French-speaking resident who regularly expatiates on topics of interest for the speakers of English. Even this old Frenchman (his correspondence covers two decades from his $65^{\text {th }}$ to his $85^{\text {th }}$ birthday), who had never academically studied English, was able to master enough English to browse through the English section of the newspapers he avidly read. This two-way learning process suggests that more and more people could shift from one language to the other. As time went on, there were thus more bridges between the different communities, and the dividing lines, even in linguistic matters, seem to have been less strict, especially because the inhabitants of the Crescent City seem to have been more prone to intermarrying across linguistic lines. $^{7}$

Consequently, what at first sight might have appeared as a curse to many of the travelers who came to the city and compared it with Babel was more a source of wealth than an affliction. When Joseph Holt Ingraham said he had met in New Orleans "the representatives from all the unlucky families which, at the building of Babel, were dispersed over the earth" (qtd. in Upton 2008: 85), he aptly summed up this reversal. New Orleans, the new Babel, was the place of reunion of those who had been scattered by God's curse. It was the new Promised Land of those peoples who had been cursed and had atoned. Thus, what appeared to the ears of the strangers to the city as a Babel, a noisy cluster of dissonant voices unable to communicate and understand each other, was most probably a productive diversity which, eventually, gave the city a very specific voice, the voice of New Orleans, and yet, definitely, one of the voices of the United States.

Reconsidering the questions posed earlier in this essay and Noah Webster's quest for an American voice in the early phases of the construction of the young republic, it seems that American voices were more diverse than what Webster's assertion implied, although his affirmation was politically useful to the Americans attempting to severe the ties with their old motherland. The case of New Orleans suggests that, instead of a single American voice, as Webster hypothesized, the early nineteenth century was rather one of voices which could definitely be called American. More significantly, and as argued throughout this essay, although linguistic plurality existed in many cities of the United States, particularly in the Atlantic port cities, New Orleans stands out because its diversity systematically struck the ear of the widely traveled foreigners who visited the city, be they Anglophone or Francophone, be they

\footnotetext{
${ }^{6}$ To cite but the two best-known, L'Abeille de la Nouvelle-Orléans and Le Courrier de La Louisiane, both had sections in French and English, of relatively equivalent length, the two sections containing their own news, although they gave some common information.

${ }^{7}$ See chapter 6, entitled "The Creole Capital” of my book Creole City (2015).
} 
European or American, which constitutes a first sign of the originality of New Orleans, the city on her way to becoming the Creole capital of the United States.

\section{REFERENCES}

Albion, Robert, and Jennie Barnes Pope (1939). The Rise of New York, 1815-1860. New York: Scribner's.

Berquin Duvallon, Pierre Louis (1806). Travels in Louisiana and the Floridas, in the Year 1802, Giving a Correct Picture of those Countries. New York: Riley.

Bourdelais, Marjorie (2012). La Nouvelle-Orléans: Croissance démographique, intégrations urbaines et sociales (1803-1860). Bern, Berlin, Bruxelles, Frankfurt am Main, New York, Oxford, Wien: Peter Lang.

Brasseaux, Carl A., ed. (1996). A Refuge for all Ages: Immigration in Louisiana History. Vol. X of The Louisiana Purchase Bicentennial Series in Louisiana History. Lafayette: U of Southwestern Louisiana.

Dessens, Nathalie (2007). From Saint-Domingue to New Orleans: Migration and Influences. Gainesville: UP of Florida, 2007.

Dessens, Nathalie (2015). Creole City: A Chronicle of Early American New Orleans. Gainesville: UP of Florida.

Ingraham, Joseph Holt (1835). The South West by a Yankee. New York: Harper.

King James Bible (1611). King James Bible Online. $<$ http://www.kingjamesbibleonline.org/> (Accessed 15 January 2015).

Latrobe, Benjamin (2007). The Journal of Latrobe. The Notes and Sketches of an Architect, Naturalist and Traveler in the United States from 1776 to 1820. Carlisle, Mass.: Applewood.

Latrobe, John (1986). Southern Travels. Journals of John H.B. Latrobe 1834. Ed. Samuel Wilson, Jr. F.A.I.A. New Orleans: The Historic New Orleans Collection.

Laussat, Pierre Clément de (1978). Memoirs of My Life to My Son during the Years 1803 and After. Transl. and Ed. Sister Agnes-Josephine Pastwa. Baton Rouge: Louisiana State UP.

Martineau, Harriet (1838). Retrospect of Western Travel. New York: Harper.

Murray, Charles (1839). Travels to North America, During the Years 1834, 1835, 1836. New York: Harper.

Olmsted, Frederick Law (1856). A Journey in the Seaboard Slave States. New York: Dix \& Edwards.

Reinders, Robert C. (1998) End of an Era: New Orleans, 1850-1861 (1864). Gretna, La: Pelican.

Sainte-Gême Family Papers, MSS 100. The Historic New Orleans Collection, New Orleans.

Upton, Dell (2008). Another City. Urban Life and Urban Space in the New American Republic. New Haven and London: Yale UP. 
Usner, Daniel H., Jr. (2003). American Indians in the Lower Mississippi Valley: Social and Economic Histories (Indians of the Southeast). Lincoln: U of Nebraska P.

Webster, Noah (1789). Dissertations on the English Language. Boston: Thomas and Company.

Whipple, Henry (1937). Bishop Whipple's Southern Diary, 1843-1844. Minneapolis: U of Minnesota P.

Wilhelm, Paul (1973). Travels in North America, 1822-1824. Norman: U of Oklahoma P. 